A $\mathrm{C} \cup$ Rec. Nat. Prod. 15:2(2021) 122-129

records of natural products

\title{
Isolation, Characterization and Antiproliferative Activity of Secondary Metabolites from Tanacetum alyssifolium (Bornm.) Grierson
}

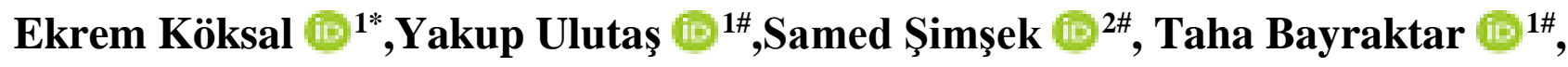 Ahmet Altay $\oplus^{1}$, Mustafa Çatır $\oplus^{1}$, İbrahim Demirtaş $\oplus^{3}$, Ali Rıza Tüfekçi $\oplus^{4}$, Ali Kandemir $\oplus^{5}$, Cemalettin Alp $\oplus^{1,2}$, Mohammed B. Anwer Alemdar $\oplus^{1}$ and Hüseyin Akşit $\oplus^{6}$}

\footnotetext{
${ }^{1}$ Erzincan Binali Ylldırım University, Faculty of Science and Art, Department of Chemistry, Erzincan, 24100 Türkiye

${ }^{2}$ Erzincan Binali Yıldırım University, Çayırlı Vocational School, Department of Medical Services and Techniques, Erzincan, 24500 Türkiye

${ }^{3}$ Iğdır University, Faculty of Science and Art, Department of Biochemistry, Iğdır, 76000 Türkiye

${ }^{4}$ Çankırı Karatekin University, Faculty of Science, Department of Chemistry, Çankırl, 18100 Türkiye

${ }^{5}$ Erzincan Binali Yıldırım University, Faculty of Science and Art, Department of Biology, Erzincan, 24100 Türkiye

${ }^{6}$ Erzincan Binali Ylldirtm University, Faculty of Pharmacy, Department of Analytical Chemistry, Erzincan, 24100 Türkiye
}

(Received July 02, 2020; Revised September 02, 2020; Accepted September 07, 2020)

\begin{abstract}
Secondary metabolites of Tanacetum alyssifolium (Bornm.) Grierson (Asteraceae) were investigated for the first time. Thirteen compounds including axillarin (1), Luteolin-7- $O$ - $\beta$-glucoside (8) and rutin (13) as flavonoids, fraxetin (7), isofraxidin (9), isofraxidin-7-O-glucoside (11) and fraxidin (12) as coumarins, tatridin A (2), altissin (3), tamirin (4) and tanachin (5) as sesquiterpene lactones and 2,4-dihydroxy-6-methoxy acetophenone (6) and picein (10) as acetophenone derivatives were isolated from the methanol extract of the species. The structures of all isolated compounds were elucidated by $1 \mathrm{D}$ and 2D-NMR techniques and by comparing with the literature data. In addition, in vitro cytotoxic activity of all isolated compounds was evaluated against breast cancer MCF-7 cell line by XTT assay. Sesquiterpene lactones; tatridin A (2), tamirin (4) and tanachin (5) were found to be the most cytotoxic molecules against MCF-7 cell line.
\end{abstract}

Keywords: Tanacetum alyssifolium; sesquiterpene lactones; cytotoxicity; MCF-7 cell line. (C) 2020 ACG Publications. All rights reserved.

\footnotetext{
* Corresponding author: E-Mail: koksalekrem@gmail.com; Phone: +905053694816

\# These authors contributed equally to this work.
} 


\section{Introduction}

Members of Tanacetum (Asteraceae), which display several kinds of biological activities, have been used in folk medicine for many centuries due to their excellent medicinal value. The large number of sesquiterpenoids and sesquiterpene lactones were isolated from Tanacetum species previously having large spectrum biological activities. This class of secondary metabolites might be responsible for these effects. Tanacetum species also contain other secondary metabolites such as coumarins, flavonoids, and steroids [1]. Plant secondary metabolites may have important biological activities such as reducing agents, free radical scavengers, or antimicrobial activities [2,3]. Such structures are vital in the defense systems of humans, as they have anti-aging, anti-inflammatory, antioxidant and anti-proliferative activities [4, 5]. Tanacetum species have long been used in many parts of the world for the treatment of certain diseases by traditional methods. Although it is most commonly known that Tanacetum vulgare L. has an anthelmintic effect and Tanacetum parthenium L. has an antipyretic effect, the effective use of other species due to their antiseptic, antibiotic, antioxidant and anti-inflammatory potentials has led them to be preferred in traditional medicine, and these species have been used as folk remedies in Anatolia for many years [6].

Tanacetum alyssifolium is locally called "Iliç papatyas1" in Turkish [7], and it is distributed in fragmented, small groups in gypsum-bearing areas only in the İliç district of Erzincan in Anatolia. It was first collected from Erzincan in 1989 and introduced to science as a new species. The species was recollected in 2004. The populations of the species were re-analyzed and the IUCN category was proposed as EN [B2ab (i, ii, iii); C2a (i)] in 2015 [8]. It is a perennial plant whose blooming period is June and July.

Although the essential oil content of Tanacetum alyssifolium was investigated, limited studies were found in the literature regarding the isolation of its secondary metabolites. The present study is the first phytochemical study to attempt the determination of secondary metabolites of Tanacetum alyssifolium which is endemic to Turkey.

In the present study, secondary metabolites of Tanacetum alyssifolium were isolated and characterized by different NMR methods and their antiproliferative activities against the MCF-7 cancer cell line were investigated.

\section{Materials and Methods}

\subsection{General}

The column chromatography (CC) was performed on silica gel, sephadex LH-20. MPLC system was used for $\mathrm{C} 18$ packing material using solvent mixtures described in the experimental sections. Fractions were monitored by TLC silica gel $60 \mathrm{~F}_{254}$ after visualizing under UV (254 and $366 \mathrm{~nm}$ ) and with ethanol-sulfuric acid reagent on silica gel followed by heating at $100{ }^{\circ} \mathrm{C}$.

The 1D and 2D NMR spectra were recorded using Bruker AVANCE III 400, and Agilent 600 $\mathrm{MHz}$ spectrometers. Chemical shifts were reported in $\delta$ values in appropriate deuterated solvents. HETCOR, COSY, HMBC, and NOESY experiments were performed to determine of both C-C and C-H interactions to elucidate the structures of the isolated molecules.

\subsection{Biological Activity}

\subsubsection{Cell Culture and Reagents}

The breast adenocarcinoma cell line MCF-7 was obtained from the ATCC (American Type Culture Collection, LGC Promochem, UK). The cancer cells were cultured in EMEM (Eagle's Minimum Essential Medium), supplemented with 1\% L- Glutamine, $1 \%$ Na-pyruvate, $1 \%$ penicillin-streptomycin (Pen Strep) solution and $10 \%$ fetal bovine serum. Cell cultures were humidified at $37^{\circ} \mathrm{C}$ with $5 \%$ carbon dioxide in an incubator. All studies were performed in a Class II Safety Cabinet. 


\subsection{Cell Viability Assay}

To perform the cell viability assay, the MCF-7 cells $(100 \mu \mathrm{L})$ were seeded in 96-well plates at a concentration of $5 \times 10^{3}$ cells/well and incubated in a $\mathrm{CO}_{2}$ incubator for $24 \mathrm{~h}$. Next, the cells were treated with the isolated compounds (1-13) for $24 \mathrm{~h}$. Each compound was dissolved in DMSO (dimethyl sulfoxide) and diluted with complete medium between the range of 2 to $500 \mu \mathrm{M}$. Complete medium containing $0.5 \%$ DMSO was used as negative control group. After the incubation of the cancer cells with the tested compounds, the absorbance of each well was measured colorimetrically at $450 \mathrm{~nm}$ by Epoch Microplate Reader (BioTek, USA). Antiproliferative activity results were expressed as $\mathrm{IC}_{50}(\mu \mathrm{M})$ value, which is defined as the concentration of the tested complex that reduces the cellular viability by $50 \%$. Each value represents the standard deviation of three independent experiments $( \pm$ S.D). Doxorubicin that is commonly used to treat cancer was evaluated as a reference drug.

\subsection{Statistical Analysis}

Statistical analyses were performed for evaluation of cytotoxicity assay results by one-way ANOVA with unpaired t-test using the statistical program GraphPad Prism 6 (GraphPad, La Jolla, CA, Software 7.0). All results were expressed as means with their standard deviation (SD). The minimum level of significance was taken as $\mathrm{p}<0.05$.

\subsection{Plant Material}

T. alyssifolium was collected from Yahşiler Village, Kemah, Erzincan at flowering stage in June 2014. A voucher specimen was authenticated by Prof. Dr. Ali Kandemir and deposited at Gazi University Herbarium (AK10111).

\subsection{Extraction and Isolation}

Well-grounded aerial parts of $T$. alyssifolium $(1.5 \mathrm{~kg})$ were extracted with hexane $(5 \mathrm{x} 4 \mathrm{~L})$, and methanol $(5 \times 4 \mathrm{~L})$, successively, then solvents were evaporated. The methanol extract was suspended in water at $60{ }^{\circ} \mathrm{C}$ then cooled and non-soluble parts were removed by filtration. The solution was extracted with ethyl acetate and butanol, respectively. The final water solution was lyophilized and kept at $4{ }^{\circ} \mathrm{C}$. A portion of the EtOAc extract $(50 \mathrm{~g})$ was applied to $\mathrm{SiO}_{2}$ column chromatography $(\mathrm{CC})$ then eluted with DCM-EtOAc-MeOH. A gradient of increasing polarity was employed, starting at $10 \%$ dichloromethane and finishing with methanol using $400 \mathrm{~mL}$ of each mixture. A total of 196 fractions were collected and similar fractions were combined to afford 13 subfractions. The subfraction $4(10 \mathrm{~g})$ was applied to $\mathrm{SiO}_{2}$ CC eluting with DCM-MeOH mixture by increasing polarity by $0.5 \%$ for every $200 \mathrm{~mL}$. After checking TLC, 7 subfractions were obtained. The subfraction 5 was purified over $\mathrm{SiO}_{2}$ to give $1(200 \mathrm{mg}) .10 \mathrm{~g}$ of EtOAc extract was fractionated over MPLC equipped with a C18 packed glass column using the mixtures of MeOH:Water as mobile phase with $10 \mathrm{~mL} / \mathrm{min}$ flow rate: 0:100, 10:90, 20:80, 30:70, 40:60 and finally 50:50. The fractions eluted with 20:80 mixture were combined and evaporated to dryness. The EtOAc soluble parts of this fraction were applied to $\mathrm{SiO}_{2} \mathrm{CC}$ and eluted isocratically by 60:40 hexaneEtOAc mixture. The flow rate was adjusted to about $0.1 \mathrm{~mL} / \mathrm{min}$. A total of 82 fractions were collected and similar fractions were combined to give 6 subfractions. The subfractions from 3 to 6 were purified using prep-HPLC over C18 prep-scale column (50:50 MeOH:Water, $235 \mathrm{~nm}, 8 \mathrm{~mL} / \mathrm{min})$ to give 2 (12 $\mathrm{mg}), \mathbf{3}(17 \mathrm{mg}), \mathbf{4}(9 \mathrm{mg})$ and $\mathbf{5}$ (34 $\mathrm{mg})$, respectively.

The $\mathrm{BuOH}$ extract was evaporated to dryness $(40 \mathrm{~g})$ and then applied to $\mathrm{SiO}_{2}$ column eluting with increasing polarity of hexane-DCM-EtOAc-MeOH to afford 13 (A1 to A13) main fractions according to TLC basis. A2 was applied to Sephadex LH-20 using $\mathrm{MeOH}: \mathrm{CHCl}_{3}(60: 40)$ as mobile phase. 20 fractions in total were collected and the subfractions between 15-17 were eluted over C18 using the following mixtures of $\mathrm{MeOH}: \mathrm{H}_{2} \mathrm{O}: 1: 9,2: 8,3: 7,4: 6$ and 5:5. Altogether 28 fractions were collected. After TLC development, fractions 12-19 were combined and purified over sephadex LH-20 to give 6 (18 mg). The main fraction $\mathrm{A} 5$ was fractioned over $\mathrm{SiO}_{2}$ using hexane-EtOAc-MeOH system with increasing polarity and 42 fractions were collected. Fractions 7-14 were combined according to TLC profile and purified 
over sephadex LH-20 to give 7 (24 mg). Fractions of A7-A9 were combined ( $8 \mathrm{~g})$ then applied on sephadex LH-20 using $\mathrm{MeOH}: \mathrm{CHCl}_{3}(65: 35)$ as mobile phase to give $8(84 \mathrm{mg})$ and $\mathbf{9}(25 \mathrm{mg})$. A11 was eluted over sephadex LH-20 as above to afford $\mathbf{1 0}(8 \mathrm{mg})$ from the 56th fraction of 70 subfractions. A13 was fractioned over sephadex LH-20 using $\mathrm{MeOH}: \mathrm{CHCl}_{3}$ (60:40) and 24 fractions were collected. Two main subfractions were obtained according to TLC. The subfraction 1 purified over sephadex LH-20 to give $11(18 \mathrm{mg})$. The subfraction 2 was applied to $\mathrm{SiO}_{2} \mathrm{CC}$ eluting with 6:4 (EtOAc:Hexane). The fractions $16-24$ gave 12 ( $34 \mathrm{mg}$ ).

The water extract firstly fractionated with MPLC over C18 packed column using water:MeOH mixture as mobile phase with $20 \mathrm{~mL} / \mathrm{min}$ flow rate with increasing $\mathrm{MeOH}$ starting from 0:100 to 100:0. Totally 70 fractions were collected and combined according to TLC view to give 6 subfractions. The subfraction 4 was chromatographed over $\mathrm{C} 18 \mathrm{CC}$ with 65:35 water: $\mathrm{MeOH}$ system, isocratically to give 36 fractions which was combined in three groups. The second group was purified over sephadex LH-20 column using $\mathrm{MeOH}$ as mobile phase to give $\mathbf{1 3}(38 \mathrm{mg})$ and $\mathbf{9}(24 \mathrm{mg})$.

\section{Results and Discussion}

The methanol extract of the aerial parts of T. alyssifolium afforded two acetophenone derivatives: 2,4-dihydroxy-6-methoxy acetophenone (6) [9] and picein (10) [10], three flavonoids; axillarin (1) [11], Luteolin-7- $O-\beta$-glucoside (8) [12] and rutin (13) [13], four sesquiterpene lactones tatridin A (2) [14], altissin (3) [15], tamirin (4) and tanachin (5) [16], four coumarin derivatives; fraxetin (7) [17], isofraxidin (9) [18], isofraxidin-7-O-glucoside (11) [19] and fraxidin (12) [20]. The occurrence of acetophenone derivatives (6 and 10) in Tanacetum species was firstly reported in this study. Flavone derivatives were common for Tanacetum species [21-23].<smiles>COc1c(O)cc2oc(-c3ccc(O)c(O)c3)c(OC)c(=O)c2c1O</smiles>

1

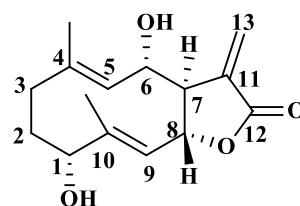

2<smiles>C=C1C(=O)O[C@H]2C[C@]3(C)[C@@H](O)CC=C(C)[C@H]3[C@H](O)[C@H]12</smiles>

3<smiles>C=C1C(=O)O[C@H](C)[C@H]1[C@H](O)CC(C)(C)C(=O)CC/C(C)=C\C</smiles>

4

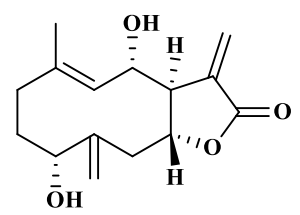

5<smiles>COc1cc2ccc(=O)oc2c(OC)c1O</smiles>

9<smiles>COc1cc(O)cc(O)c1C(C)=O</smiles>

6<smiles>COc1cc2ccc(=O)oc2c(O)c1O</smiles><smiles>COc1cc(O)c2c(=O)cc(-c3ccc(O)c(O)c3)oc2c1</smiles>

8

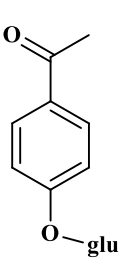

10<smiles>COc1cc2ccc(=O)oc2c(OC)c1O[Na]</smiles>

11<smiles>COc1cc2ccc(=O)oc2cc1OC</smiles>

12
13

Figure 1. Chemical structures of isolated molecules (1-13)

Although rutin and axillarin content of some Tanacetum species were previously reported [24, $25]$, the occurrence of luteolin-7-O- $\beta$-glucoside was not reported in any Tanacetum species up to date. Tanacetum species are known to be rich in sesquiterpene lactones [26-29]. Although tatridin A, tamirin and tanachin were isolated from T. vulgare previously [30], altissin was not reported before in Tanacetum species. Coumarin derivatives such as scopoletin from $T$. cadmeum [31], isofraxidin from $T$. chiliophyllum [32] and T. parthenium [33] were reported previously. Chemical structures of all isolated molecules from T. alyssifolium are given in Figure 1. 
The antiproliferative activities of the compounds (1-13) against the MCF-7 cell line were evaluated by XTT assay, which is based on the extracellular reduction of XTT salt by Nicotinamide Adenine Dinucleotide (NADH) in mitochondria. The cancer cells were treated with each compound for $24 \mathrm{~h}$ at varying concentrations $(2,10,25,50,100$, and $500 \mu \mathrm{M})$. The results showed that the acetophenone derivatives $(\mathbf{6}$ and $\mathbf{1 0})$, flavonoid derivatives $(\mathbf{1}, \mathbf{8}$, and 13) and coumarin derivatives $(\mathbf{7}, \mathbf{9}$, 11, and 7) displayed no activity up to $500 \mu \mathrm{M}$ against MCF-7 cell line, while the sesquiterpene lactone derivatives (2, 3, 4 and 5) exhibited very high cytotoxic activities. Figure S28 ( see supporting information file) shows the dose dependent cytotoxic activity of the sesquiterpene lactones $(\mathbf{2}, \mathbf{3}, \mathbf{4}$, and 5). The compounds $2, \mathbf{4}$ and 5 showed dose-dependent cytotoxic activities between the ranges of 2-100 $\mu \mathrm{M}$. The $\mathrm{IC}_{50}$ values of the compounds are given in the Table 1 . The sesquiterpene lactone 4 exhibited the highest cytotoxic activity with the smallest $\mathrm{IC}_{50}$ value $(40.8 \mu \mathrm{M})$. The $\mathrm{IC}_{50}$ values of the other two sesquiterpene lactones 2 and $\mathbf{5}$ were found as $57.1 \mu \mathrm{M}$ and $65.8 \mu \mathrm{M}$, respectively. Considering the $\mathrm{IC}_{50}$ value of doxorubicin $(2,92 \mu \mathrm{M})$, the compounds $(\mathbf{2}, \mathbf{4}$, and 5) showed remarkable cytotoxic activity against the MCF-7 cell line. On the other hand, acetophenone derivatives (6 and 10), coumarin derivatives $(\mathbf{7}, \mathbf{9}, \mathbf{1 1}$, and 12), and flavonoid derivatives $(\mathbf{1}, \mathbf{8}$, and $\mathbf{1 3})$ did not show cytotoxic activity up to $500 \mu \mathrm{M}$.

The molecular structures, location of the functional groups, and the relative configurations of sesquiterpene lactones significantly changes the cytotoxic effect and $\mathrm{IC}_{50}$ value of the compounds [34, 35]. Robinson et al. tested six sesquiterpene lactones from Saussurea lappa for their anticancer activity on Colo-205, A-431, A-549, and MCF-7 cell lines. The $\mathrm{IC}_{50}$ values of the sesquiterpene lactones against MCF-7 cell lines were measured between the range of 35.1 to $103.4 \mu \mathrm{g} / \mathrm{mL}$. However, the same compounds were found not to show cytotoxic activity against A-549 cell line, indicating the susceptibility of the different cancer cell lines to the same lactone compound [36]. Therefore, our results were in accordance with the studies in the literature.

Table 1. In vitro $\mathrm{IC}_{50}$ values of the compounds (1-13) and doxorubicin against MCF-7 cell line

\begin{tabular}{cc}
\hline Compounds & $\mathbf{I C}_{\mathbf{5 0}}(\boldsymbol{\mu M})^{\mathbf{x}}$ \\
\hline $\mathbf{1}$ & $\mathrm{NA}$ \\
$\mathbf{2}$ & $57.1 \pm 0.92^{\mathbf{a}}$ \\
$\mathbf{3}$ & $\mathrm{NT}$ \\
$\mathbf{4}$ & $40.8 \pm 1.13^{\mathbf{b}}$ \\
$\mathbf{5}$ & $65.8 \pm 1.35^{\mathbf{c}}$ \\
$\mathbf{6}$ & $\mathrm{NA}$ \\
$\mathbf{7}$ & $\mathrm{NA}$ \\
$\mathbf{8}$ & $\mathrm{NA}$ \\
$\mathbf{9}$ & $\mathrm{NA}$ \\
$\mathbf{1 0}$ & $\mathrm{NA}$ \\
$\mathbf{1 1}$ & $\mathrm{NA}$ \\
$\mathbf{1 2}$ & $\mathrm{NA}$ \\
$\mathbf{1 3}$ & $\mathrm{NA}$ \\
${ }^{*}$ Doxorubicin & $2,92 \pm 0.85^{\mathbf{d}}$ \\
\hline
\end{tabular}

The cytotoxic activity of the three sesquiterpene lactones in Table 1 were in the decreasing order of $\mathbf{4}>\mathbf{2}>\mathbf{5}$. If we consider their structures, the only difference between $\mathbf{4}$ and $\mathbf{5}$ is that the group at $\mathrm{C} 1$ position changes from a carbonyl in $\mathbf{4}$ to a hydroxyl in $\mathbf{5}$. This indicates that the mechanism of cytotoxicity is different in these two compounds. The presence of the carbonyl group instead of the hydroxyl at $\mathrm{C} 1$ may cause more induction of cytotoxic activity in the cell line. On the other hand, considering the structures of $\mathbf{2}, \mathbf{4}$, and $\mathbf{5}$, instead of the methyl group at $\mathrm{C} 10$ in $\mathbf{2}$, there is an exocyclic methylene group at the same position in $\mathbf{4}$ and $\mathbf{5}$. This is also consistent with the common notion that $\alpha$ methylene- $\gamma$-lactone moiety of sesquiterpene lactones is responsible for their diverse biological activities including cytotoxicity because of its interaction with biological nucleophiles, such as thiol groups (SH) of target proteins [37]. 
As a result, the primary cytotoxicity results of the sesquiterpene lactones, especially compounds $\mathbf{2}, \mathbf{4}$, and $\mathbf{5}$ may be a good starting point for further investigations of cytotoxic activity on other cancer cell lines, as well as mechanisms of activity and structure activity relationships.

\section{Acknowledgments}

This project is supported by the Erzincan Binali Yıldırım University Scientific Research Projects Coordination Unit (FEN-A-220114-0062). The authors extend special thanks to Ömer Faruk Ensari for recording the NMR spectra.

\section{Supporting Information}

Supporting information accompanies this paper on http://www.acgpubs.org/journal/records-ofnatural-products

\section{ORCID}

Ekrem Köksal: 0000-0002-1026-972X

Yakup Ulutaş: 0000-0002-9839-9536

Samed Şimşek: 0000-0001-8451-3425

Taha Bayraktar: 0000-0001-9369-6569

Ahmet Altay: 0000-0001-8120-8900

Mustafa Çatır: 0000-0002-8705-0443

İbrahim Demirtaş: 0000-0001-8946-647X

Ali Rıza Tüfekçi: 0000-0002-2951-3657

Ali Kandemir: 0000-0003-1902-9631

Cemalettin Alp: 0000-0001-6213-7297

Mohammed Alm: 0000-0002-1197-3778

Hüseyin Akşit: 0000-0002-1509-851X

\section{References}

[1] M.J. Abad, P. Bermejo and A. Villar (1995). An approach to the genus Tanacetum L.(Compositae): phytochemical and pharmacological review, Phytother. Res. 9, 79-92.

[2] E. Köksal (2011). Peroxidase from leaves of Spinach (Spinacia oleracea): Partial purification and some biochemical properties, Int. J. Pharmocol. 7, 135-139.

[3] R.D. Lindsay (1996). Flavors in Food Chemistry 3rd edition ed.: Marcel Dekker Inc.

[4] A. Bower, S. Marquez and E.G. de Mejia (2016). The health benefits of selected culinary herbs and spices found in the traditional Mediterranean diet, Crit. Rev. Food Sci. Nutr. 56, 2728-2746.

[5] M.B. Bahadori, M. Eskandani, M. De Mieri, M. Hamburger and H. Nazemiyeh (2018). Anti-proliferative activity-guided isolation of clerodermic acid from Salvia nemorosa L.: Geno/cytotoxicity and hypoxiamediated mechanism of action, Food Chem. Toxicol. 120, 155-163.

[6] T. Baytop (1999). Türkiye'de Bitkiler İle Tedavi İstanbul: Nobel Yayınları.

[7] A. Güner (2012). Türkiye Bitkileri Listesi (Damarlı Bitkiler) İstanbul: ANG Vakfi.

[8] A. Kandemir, M. Korkmaz and C.Ş.Ç Sevindi (2015). Erzincan (Türkiye)'a Özgü Endemik Bitki Taksonlarının IUCN Tehdit Kategorileri, Bağbahçe Bil. Derg. 2, 43-65.

[9] Z.Q, Yin, C.L. Fan, W.C. Ye, R.W. Jiang, C.T. Che, T.C. Mak and X.S. Yao (2005). Acetophenone derivatives and sesquiterpene from Euphorbia ebracteolata, Planta Med. 71, 979-982.

[10] J. Dou, W. Xu, J.J. Koivisto, J.K. Mobley, D. Padmakshan, M. Kögler and T. Vuorinen (2018). Characteristics of hot water extracts from the bark of cultivated willow (Salix sp.), ACS Sustain. Chem. Eng. 6, 5566-5573.

[11] J. Hu, W. Ma, N. Li and K.J. Wang (2017). Antioxidant and anti-inflammatory flavonoids from the flowers of Chuju, a medical cultivar of Chrysanthemum morifolim Ramat, J. Mex. Chem. Soc. 61, 282-289. 
[12] Z. Özer, S. Çarıkçı, H. Yılmaz, T. Kılıç, T. Dirmenci and A.C. Gören (2020). Determination of secondary metabolites of Origanum vulgare subsp. hirtum and $O$. vulgare subsp. vulgare by LC-MS/MS, J. Chem. Metrol. 14, 24-35.

[13] J.Y. Lallemand and M. Duteil (1977). ${ }^{13} \mathrm{C}$ NMR spectra of quercetin and rutin, Org. Magn. Reson. 9, 179180.

[14] R.E. Craig, J.A. Campbell, A.C. Craig, C.F. Campana and R.G. Kelsey (1990). Tatridin A from Artemisia arbuscula ssp. arbuscula: Crystal structure of tatridin A diacetate and the identification of deacetyltulirinol, J. Nat. Prod. 53, 1585-1586.

[15] M. Konstantinopoulou, A. Karioti, S. Skaltsas and H. Skaltsa (2003). Sesquiterpene lactones from Anthemis altissima and their Anti-Helicobacter pylori activity, J. Nat. Prod. 66, 699-702.

[16] M.K. Makhmudov, B.K. Abduazimov, B. Tashkhodzhaev and B.T. Ibragimov (1989). Spatial structures of the sesquiterpene germacrane lactones tanachin and tamirin, Chem. Nat. Comp. 25, 168-173.

[17] R. Liu, Q. Sun, A. Sun and J. Cui (2005). Isolation and purification of coumarin compounds from Cortex fraxinus by high-speed counter-current chromatography, J. Chromatogr. A. 1072, 195-199.

[18] T. Takemoto, M. Uchida, K. Koike, Y. Hoshina and G. Kusano (1975). Studies on the constituents of Chloranthus spp. I. The structures of two new amides from Chloranthus serratus and the isolation of isofraxidin from C. japonicus, Chem. Pharm. Bull. 23, 1161-1163.

[19] Q.J. Li, M.L. Wang, X.S. Yang, L. Ma and X.J. Hao (2013). Two new coumarin glycosides from Chimonanthus nitens, J. Asian Nat. Prod. Res. 15, 270-275.

[20] H.B. Hu, X.D. Zheng, Y.F. Jian, J.X Liu and J.H. Zhu (2011). Constituents of the root of Anemone tomentosa, Arch. Pharm. Res. 34, 1097-1106.

[21] S.H. Hwang, H.Y. Kim, Y.N.G Quispe, Z. Wang, G. Zuo and S.S. Lim (2019). Aldose reductase, protein glycation inhibitory and antioxidant of Peruvian medicinal plants: The case of Tanacetum parthenium $\mathrm{L}$. and its constituents, Molecules 24, 2010-2016.

[22] M. Juan-Badaturuge, S. Habtemariam, C. Jackson and M.J. Thomas (2009). Antioxidant principles of Tanacetum vulgare L. aerial parts, Nat. Prod. Commun. 4, 1561-1564

[23] M. Mureşan, D. Benedec, L. Vlase, R. Oprean, A. Toiu and I. Oniga (2015). Screening of polyphenolic compounds, antioxidant and antimicrobial properties of Tanacetum vulgare from Transylvania, Stud. U. Babes-Bol. Che. 60, 127-138.

[24] Á.L. Álvarez, S. Habtemariam, M. Juan-Badaturuge, C. Jackson and F. Parra (2011). In vitro anti HSV-1 and HSV-2 activity of Tanacetum vulgare extracts and isolated compounds: An approach to their mechanisms of action, Phytother. Res. 25, 296-301.

[25] A.G. Gonzalez, J.T. Mendez, M.L. Sanchez and J.L.E Martinez (1990). Sesquiterpene lactones from Tanacetum ferulaceum, Phytochemistry 29, 2339-2341.

[26] M. Abad, P. Bermejo, S. Valverde and A. Villar (1994). Anti-inflammatory activity of hydroxyachillin, a sesquiterpene lactone from Tanacetum microphyllum, Planta Med. 60, 228-231.

[27] F. Bohlmann and C. Zdero (1982). Sesquiterpene lactones and other constituents from Tanacetum parthenium, Phytochemistry 21, 2543-2549.

[28] N. Gören, J. Jakupovic and Ş. Topal (1990). Sesquiterpene lactones with antibacterial activity from Tanacetum argyrophyllum var. argyrophyllum, Phytochemistry 29, 1467-1469.

[29] N. Gören, H.J. Woerdenbag and C. Bozok-Johansson (1996). Cytotoxic and antibacterial activities of sesquiterpene lactones isolated from Tanacetum praeteritum subsp. Praeteritum, Planta Med. 62, 419-422.

[30] J.F. Sanz and J.A. Marco (1991). NMR studies of tatridin A and some related sesquiterpene lactones from Tanacetum vulgare, J. Nat. Prod. 54, 591-596.

[31] H. Susurluk, Z. Çalışkan, O. Gürkan, S. Kırmızıgül and N. Gören (2007). Antifeedant activity of some Tanacetum species and bioassay guided isolation of the secondary metabolites of Tanacetum cadmeum ssp. cadmeum (Compositae), Ind. Crops Prod. 26, 220-228.

[32] K. Polatoğlu, Y.Y. Yücel, A. Nalbantsoy, H.T. Yalçin and N. Gören (2017). Cytotoxic, antimicrobial activities, AChE and BChE inhibitory effects of compounds from Tanacetum chiliophyllum (Fisch. \& Mey.) Schultz Bip. var. oligocephalum (DC) Sosn. and T. chiliophyllum (Fisch. \& Mey.) Schultz Bip. var. monocephalum Grierson, Phytochem. Lett. 22,199-204.

[33] W. Kisiel and A. Stojakowska (1997). A sesquiterpene coumarin ether from transformed roots of Tanacetum parthenium, Phytochemistry 46, 515-516.

[34] E.M. Maldonado, D. Svensson, S.M. Oredsson and O. Sterner (2014). Cytotoxic sesquiterpene lactones from Kauna lasiophthalma Griseb, Sci. Pharm. 82, 147-160.

[35] C.M. Wang, Z.J. Jia and R.L. Zheng (2007). The effect of 17 sesquiterpenes on cell viability and telomerase activity in the human ovarian cancer cell line HO-8910, Planta Med.73, 180-184. 
[36] A. Robinson, T.V. Kumar, E. Sreedhar, V. Naidu, S.R. Krishna, K.S. Babu, P. Srinivas and J.M. Rao (2008). A new sesquiterpene lactone from the roots of Saussurea lappa: Structure-anticancer activity study, Bioorg. Med. Chem. Lett. 18, 4015-4017.

[37] A. Bosco and R.M. Golsteyn (2017). Emerging anti-mitotic activities and other bioactivities of sesquiterpene compounds upon human cells, Molecules 22, 459-484.

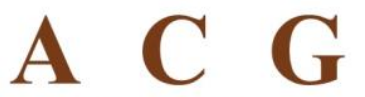

publications

(C) 2020 ACG Publications 